American Journal of Environmental Sciences 4 (5): 535-543, 2008

ISSN 1553-345X

(C) 2008 Science Publications

\title{
Comparison and Parametric Study of Flameless Oxidation in a Gas Turbine Using Two Kinetics Mechanisms
}

\author{
${ }^{1}$ Mohamed Hamdi, ${ }^{1}$ Hmaïed Benticha and ${ }^{2}$ Mohamed Sassi \\ ${ }^{1}$ Laboratoire d'Etudes des Systèmes Thermiques et Energétiques, \\ Ecole Nationale d'Ingénieurs de Monastir, 5019, Monastir, Tunisie \\ ${ }^{2}$ The Petroleum Institute, P.O. Box 2533, Abu Dhabi, UAE
}

\begin{abstract}
The so-called "Flameless Oxidation" is a novel combustion mode, in which combustion products are re-circulated and mixed into the fresh incoming fuel and air streams. This reduces the concentration of the reactants and thereby reducing the reaction rate through avoiding the formation of sharp high temperature zones in the combustion chamber. Flameless combustion has been acknowledged as one of the most interesting combustion technologies to meet both the targets of high energy efficiency and low pollutant emissions. This technology has already been successfully applied and exploited in industrial burners. The present investigation is concerned with the application of the flameless combustion mode to an adiabatic combustor, typically used in gas turbine engines. Detailed chemical kinetics calculations, by means of a specific zero-dimensional loop reactor model, have been performed to analyze its chemical aspects. The model simulates the combustor by a number of reactors that represent different zones in the combustion chamber. The main objective of this study is to increase the understanding of $\mathrm{NO}_{\mathrm{x}}$ formation from flameless mode, where currently very few experimental data are available. The investigation is focused on a comparison of the influence of pressure, residence time and temperature on the $\mathrm{NO}_{\mathrm{x}}$ and $\mathrm{CO}$ emissions, using two reaction mechanisms of the $\mathrm{C} / \mathrm{H} / \mathrm{O} / \mathrm{N}$ system: the Miller-Bowman mechanism and the GRI_MECH3.0 mechanism. Simulation results clearly illustrate that even at high operating temperatures and pressures, $\mathrm{NO}_{\mathrm{x}}$ emissions could be reduced by flameless combustion to very low levels. A comparison between the predictions obtained by using the two chemical kinetics mechanisms is presented and discussed. It is shown that the predictions of the Miller-Bowman mechanism deviate from the predictions of the GRI3.0 mechanism in many aspects, especially as related to $\mathrm{NO}_{\mathrm{x}}$ emission results.
\end{abstract}

Key words: Flameless oxidation, gas turbines, pollutants emissions, numerical modeling, detailed chemical mechanism

\section{INTRODUCTION}

Environmental concerns and limited resources of fuels have been the major constraints in designing combustion systems. These constraints have triggered researchers and manufacturers of combustion systems to develop low polluting and fuel-efficient combustion systems. The major pollutants produced by combustion are unburned and partially burned hydrocarbons, nitrogen oxides or $\mathrm{NO}_{\mathrm{x}}\left(\mathrm{NO}, \mathrm{NO}_{2}\right)$, carbon monoxide (CO) and sulphur oxides $\left(\mathrm{SO}_{2}\right.$ and $\left.\mathrm{SO}_{3}\right)$. Nitrogen oxide is one of the most toxic pollutants in the atmosphere and is well known as a destroyer of stratospheric ozone and a precursor of acid rain. Different process alternatives have been proposed to reduce the emissions from combustion devices. These include, for example, exhaust gas recirculation, air staging, re-burning and low $\mathrm{NO}_{\mathrm{x}}$ burners. In general, these methods try to reduce the residence time in high temperature regions, or to avoid high oxygen concentration in such regions. In this way, the formation of thermal NO is largely suppressed, since this mechanism is highly dependent on the temperature and requires temperatures above $1800 \mathrm{~K}$ to produce a significant amount of NO.

Another key issue in the design and operation of combustion equipment is the combustion efficiency. A well known method to improve combustion efficiency is to use the exhaust gases to preheat the combustion air by means of a heat exchanger. However, this method generally yields an increase of the flame temperature, resulting in an increase of thermal NO formation and $\mathrm{NO}_{\mathrm{x}}$ emissions.

In the last few years significant efforts have been made to retain the benefit of better combustion 
efficiency due to air-preheating without the adverse effect of higher $\mathrm{NO}_{\mathrm{x}}$ emissions caused by higher flame temperatures. As a result of these efforts, it was found that strong exhaust gas recirculation combined with air preheating generates relatively low flame temperatures. The combustion air is diluted with a large amount of recirculated exhaust gases and so the mass fraction of oxygen in the reaction zone is much lower than in the case of undiluted atmospheric air. Therefore, the stoeichiometric flame temperature is also lower. In addition, the temperature fluctuations are small and there is no luminosity or sound emission from the flame. This combustion regime was referred to as Flameless Oxidation or FLOX $^{\mathrm{TM}}$ by Wünning and Wünning $^{[1]}$ and was reviewed by Katsuki and Hasegawa $^{[2]}$, who emphasized the research carried out in Japan.

Although the technology of fuel combustion with highly preheated air has substantially advanced over the last decade or so, there has been relatively little work undertaken by the fundamental combustion community to support the development. The work on fundamentals of the process was initiated probably by $R$. Tanaka ${ }^{[3]}$ sometime at the beginning of the nineties. Soon afterwards Gupta et al. ${ }^{[4,5]}$ undertook research on the effect of combustion air temperature and oxygen concentration on flame colour, visibility and thermal emission spectra. Propane was used as the fuel. The researchers observed a substantial increase in radiation intensity at wavelengths corresponding to $\mathrm{C}_{2}$ radicals emission with the preheated air temperature under low oxygen concentration conditions. Mochida and Hasegawa $^{[6]}$ have developed a flame visualization technique based on the luminescence intensity ratio of $\mathrm{C}_{2}$ and $\mathrm{CH}$ radicals. Blasiak et $a .^{[7]}$ built an experimental facility for studying fuel jets immersing into a cross-flowing high temperature air stream to enhance mixing and attain flameless conditions. The IFRF carried out semi-industrial scale experiments (Verlaan et $a l .{ }^{[8]}$ and Weber et al. ${ }^{[9]}$ ) that identified the principal characteristics of the flameless combustion process. The furnace was operated almost like a wellstirred reactor. The measured radiative heat fluxes at the furnace walls were very high and uniform. Uniformity and homogenization of flameless combustion of methane and propane with highly preheated air $\left(1000^{\circ} \mathrm{C}\right)$ have been studied by Ishiguro et al. ${ }^{[10]}$. They obtained images of $\mathrm{OH}, \mathrm{CH}$ and $\mathrm{C}_{2}$ emissions for a number of experimental conditions that differed in the air preheat level and oxygen content of the air. The investigators concluded that the increase in air temperature resulted in a decrease of flame temperature gradients (homogenization of reaction zone) and low flame fluctuations. Plessing et al. ${ }^{[11]}$ used laser-induced predissociative fluorescence and Rayleigh thermometry to examine flameless oxidation at laboratory scale. They observed that the flameless oxidation takes place in the well-stirred reactor regime. The $\mathrm{OH}$ concentration in the combustion zones of flameless oxidation is lower than in nopreheated undiluted turbulent premixed flames. De Joannon et $a l^{[12]}$ have examined the applicability of the existing chemical reaction schemes for combustion of hydrocarbons to high temperature air combustion conditions. Cavaliere and De Joannon ${ }^{[13]}$ have argued that flameless oxidation can be described as a two staged combustion in which the first part is in rich conditions with plenty of inert gases.

The success of flameless combustion in furnaces motivated its application in other fields such as gas turbine engines for power generation ${ }^{[14]}$. The combustion chambers for gas turbines differ from industrial furnaces by being "almost adiabatic" without heat extraction from the combustors, by operating at elevated pressures and by maintaining significant level of oxygen concentration before combustion and even in the combustion products. These differences challenge the application of flameless combustion in gas turbine engines, especially in forming sufficient fuel/air mixing with exhaust gas dilution and generate distributed flame at high pressure conditions. In their study, Hamdi et al. ${ }^{[15]}$, showed that even at high temperature and for industrial turbine combustor-operating pressures, $\mathrm{NO}_{\mathrm{x}}$ emissions could be reduced by flameless combustion to very low levels and negligible $\mathrm{CO}$ and UHC emissions.

The present investigation is concerned with the application of the flameless combustion mode to an adiabatic combustor, typically used in a gas turbine engine. Detailed chemical kinetics calculations, by means of a specific zero-dimensional loop reactor model, have been performed to analyze its chemical aspects. The model simulates the combustor by a number of reactors that represent different zones in the combustion chamber. The investigations were focused on the influence of pressure, residence time and temperature on the $\mathrm{NO}_{\mathrm{x}}$ and $\mathrm{CO}$ emissions, so that the chemical effects of these parameters on the species concentrations can be assessed and compared using two detailed chemical kinetics mechanisms of the $\mathrm{C} / \mathrm{H} / \mathrm{O} / \mathrm{N}$ system: the Miller-Bowman mechanism ${ }^{[16]}$ and the GRI_MECH3.0 mechanism ${ }^{[17]}$. Both mechanisms are commonly used by the combustion community to simulate pollutant emissions from combustion devices. However, in this study we show that the predictions of the two kinetics mechanisms differ in many aspects especially as related to $\mathrm{NO}_{\mathrm{x}}$ emissions. 


\section{REACTIONAL KINETICS MECHANISMS AND COMBUSTOR MODEL}

We consider gas turbine combustion of natural gas with air. The combustion of natural gas is a complex process involving about 300 elementary reactions between about 50 species, to account for the fuel oxidation and the $\mathrm{NO}_{\mathrm{x}}$ formation. The tow complete reaction mechanisms of the $\mathrm{C} / \mathrm{H} / \mathrm{O} / \mathrm{N}$ system studied in this work are:

The GRI mechanism (GRI_MECH3.0): This mechanism for up to $\mathrm{C} 2$ chemistry includes 53 species and 325 reactions ${ }^{[16]}$.

The Miller-Bowman mechanism (M-B89AB): This mechanism for up to $\mathrm{C} 4$ chemistry includes 52 species and 251 reactions ${ }^{[17]}$.

The Chemkin3.6 package ${ }^{[18]}$ is used to perform the simulations. The chemical kinetics information is supplied in a chemical reaction mechanism provided by the user.

To develop a model that utilizes a detailed chemical kinetic scheme for the flameless combustion concept, a novel zero-dimensional model was developed in an earlier study ${ }^{[15]}$. The combustor is simulated by the flow model shown in Fig. 1. It consists of a simple two-reactor network modeling the turbine combustor: a Perfectly Stirred Reactor (PSR)

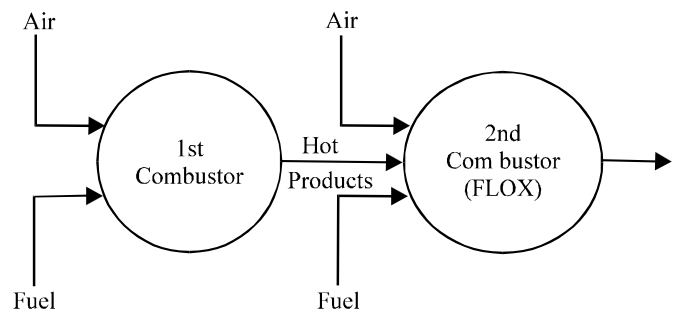

Fig. 1: Proposed combustor flow model

Table 1: The two-reactor network input conditions

\begin{tabular}{|c|c|c|c|}
\hline & $\begin{array}{l}\text { Flow rate } \\
\left(\mathrm{kg} \mathrm{sec}^{-1}\right)\end{array}$ & $\begin{array}{l}\text { Temperature } \\
(\mathrm{K})\end{array}$ & Composition (\% vol.) \\
\hline \multicolumn{4}{|c|}{ 1st combustor (conventional) } \\
\hline Natural Gas & 12.5 & 773.3 & $\begin{array}{l}\mathrm{CH}_{4}: 94.5 \% ; \mathrm{C}_{2} \mathrm{H}_{6}: 1.2 \% \text {; } \\
\mathrm{C}_{3} \mathrm{H}_{8}: 0.4 \% ; \mathrm{N}_{2}: 2.3 \% \text {; } \\
\mathrm{O}_{2}: 0.6 \%\end{array}$ \\
\hline Air & 545.5 & 773.3 & $\begin{array}{l}\mathrm{O}_{2}: 20.7 \% ; \mathrm{N}_{2}: 77 \% \\
\mathrm{H}_{2} \mathrm{O}: 1.58 \% ; \mathrm{CO}_{2}: 0.72 \%\end{array}$ \\
\hline \multicolumn{4}{|c|}{ 2nd combustor (FLOX) } \\
\hline Natural Gas & 4.0 & 1302.76 & $\begin{array}{l}\mathrm{CH}_{4}: 94.5 \% ; \mathrm{C}_{2} \mathrm{H}_{6}: 1.2 \% \text {; } \\
\mathrm{C}_{3} \mathrm{H}_{8}: 0.4 \% ; \mathrm{N}_{2}: 2.3 \% ; \\
\mathrm{O}_{2}: 0.6 \%\end{array}$ \\
\hline Air & 558.0 & 1302.76 & $\begin{array}{l}\mathrm{O}_{2}: 12.5 \% ; \mathrm{N}_{2}: 74 \% \\
\mathrm{H}_{2} \mathrm{O}: 8.77 \% \mathrm{CO}_{2}: 3.7 \%\end{array}$ \\
\hline
\end{tabular}

representing the igniter chamber by the first combustor where the fuel is mixed with the high pressure air and ignited. The hot gases exit the first combustor chamber and enter the second combustion chamber representing the FLOX process, which is also simulated by a Perfectly Stirred Reactor (PSR) where frais fuel and air mix with the combustion products of the first chamber. The input conditions of the adopted model are listed in Table 1.

\section{RESULTS AND DISCUSSION}

The influence of pressure and residence time on species concentrations at the exit of the turbine combustor model are presented and discussed in this section. First the computed results are compared with the results of Tomaz et al. ${ }^{[19]}$ for validation purposes and then the two reaction kinetics mechanisms predictions are presented and discussed.

Validation of proposed model: Tomasz et al. ${ }^{[19]}$ presented a numerical study of turbulent, non-premixed, flameless combustion for SEV-combustor using the $\mathrm{k}-\varepsilon$ turbulence model, finite-rate-eddy-beak-up combustion model and the GRI mechanism of full chemistry. In particular, Table 2 contains concentrations of species in the outlet flue gas from the second combustor, obtained from the inlet conditions shown in the Table 1, where the inlet temperature of air in the second combustor is $1302.76 \mathrm{~K}$.

Table 2 also reports the comparison of the results predicted by our model and those obtained by Tomasz et $a l .{ }^{[19]}$. We can seen a satisfactory agreement on the major species concentrations in the outlet flue gas from the second combustor, except that the concentrations of the $\mathrm{NO}_{x}\left(\mathrm{NO}, \mathrm{NO}_{2}\right.$ and $\left.\mathrm{N}_{2} \mathrm{O}\right)$ furnished by the CFD calculations are about $100 \mathrm{ppm}$ higher than the ones predicted by our simulations. This is consistent with other observations of diluted combustion studies ${ }^{[1,21,22,23,24]}$. In fact, the $\mathrm{NO}_{\mathrm{x}}$ calculation in the CFD FLUENT code can be made more or less sensitive to the local enthalpy variation due to turbulent fluctuations by using two different options to compute average $\mathrm{NO}_{\mathrm{x}}$ values from instantaneous ones. With the Top temperature option, the instantaneous temperatures used in the NO production rate equation are the maximal possible ones, giving consequently the maximum possible thermal NO production $^{[25]}$.

On the other hand we can see a high level of $\mathrm{OH}$, $\mathrm{CH}$ and $\mathrm{CO}$ radicals. This result confirms the observed characteristic color of flameless oxidation (deep green) and which follows from the high level of all these radicals. 
Am. J. Environ. Sci., 4 (5): 535-543, 2008

Table 2: Concentrations of species in the outlet of the second combustion chamber

\begin{tabular}{|c|c|c|c|c|c|}
\hline Species & $\mathrm{H} 2$ & $\mathrm{H}$ & $\mathrm{O}$ & $\mathrm{O} 2$ & $\mathrm{OH}$ \\
\hline Tomasz et al. & $0.101 \mathrm{E}-05$ & 0.164 E-07 & $1.02 \mathrm{E}-05$ & $1.02 \mathrm{E}-01$ & $6.46 \mathrm{E}-05$ \\
\hline Hamdi et al. & $4.16 \mathrm{E}-06$ & $8.09 \mathrm{E}-08$ & 2.06E-06 & 0.11456 & $8.36 \mathrm{E}-05$ \\
\hline Species & $\mathrm{H} 2 \mathrm{O}$ & $\mathrm{HO} 2$ & $\mathrm{H} 2 \mathrm{O} 2$ & $\mathrm{C}$ & $\mathrm{CH}$ \\
\hline Tomasz et al. & $1.10 \mathrm{E}-01$ & $6.00 \mathrm{E}-07$ & $5.50 \mathrm{E}-08$ & $3.67 \mathrm{E}-21$ & $8.58 \mathrm{E}-18$ \\
\hline Hamdi et al. & $9.97 \mathrm{E}-02$ & $2.08 \mathrm{E}-06$ & $9.77 \mathrm{E}-08$ & $3.21 \mathrm{E}-19$ & $1.33 \mathrm{E}-13$ \\
\hline Species & $\mathrm{CH} 2$ & $\mathrm{CH} 2(\mathrm{~S})$ & $\mathrm{CH} 3$ & $\mathrm{CH} 4$ & $\mathrm{CO}$ \\
\hline Tomasz et al. & 7.65E-14 & $1.31 \mathrm{E}-15$ & $2.29 \mathrm{E}-12$ & $6.87 \mathrm{E}-12$ & $5.39 \mathrm{E}-05$ \\
\hline Hamdi et al. & $1.23 \mathrm{E}-09$ & $1.15 \mathrm{E}-10$ & $1.19 \mathrm{E}-11$ & $1.16 \mathrm{E}-12$ & $1.88 \mathrm{E}-04$ \\
\hline Species & $\mathrm{CO} 2$ & $\mathrm{HCO}$ & $\mathrm{CH} 2 \mathrm{O}$ & $\mathrm{CH} 2 \mathrm{OH}$ & $\mathrm{CH} 3 \mathrm{O}$ \\
\hline Tomasz et al. & $4.89 \mathrm{E}-02$ & $5.49 \mathrm{E}-14$ & $1.11 \mathrm{E}-11$ & $7.75 \mathrm{E}-16$ & $1.60 \mathrm{E}-15$ \\
\hline Hamdi et al. & $4.26 \mathrm{E}-02$ & 1.03E-09 & $1.13 \mathrm{E}-06$ & $2.27 \mathrm{E}-10$ & $6.21 \mathrm{E}-10$ \\
\hline Species & $\mathrm{CH} 3 \mathrm{OH}$ & $\mathrm{C} 2 \mathrm{H}$ & $\mathrm{C} 2 \mathrm{H} 2$ & $\mathrm{C} 2 \mathrm{H} 3$ & $\mathrm{C} 2 \mathrm{H} 4$ \\
\hline Tomasz et al. & $2.82 \mathrm{E}-12$ & $5.46 \mathrm{E}-14$ & 2.49E-09 & $5.87 \mathrm{E}-17$ & $7.40 \mathrm{E}-16$ \\
\hline Hamdi et al. & $6.38 \mathrm{E}-07$ & $4.27 \mathrm{E}-12$ & $1.43 \mathrm{E}-07$ & $1.82 \mathrm{E}-10$ & 2.72E-17 \\
\hline Species & $\mathrm{C} 2 \mathrm{H} 5$ & $\mathrm{C} 2 \mathrm{H} 6$ & $\mathrm{HCCO}$ & $\mathrm{CH} 2 \mathrm{CO}$ & $\mathrm{HCCOH}$ \\
\hline Tomasz et al. & $6.10 \mathrm{E}-22$ & $2.73 \mathrm{E}-20$ & $3.74 \mathrm{E}-13$ & $1.88 \mathrm{E}-10$ & 2.23E-07 \\
\hline Hamdi et al. & 7.05E-20 & $3.93 \mathrm{E}-18$ & $1.98 \mathrm{E}-10$ & $1.98 \mathrm{E}-09$ & $4.27 \mathrm{E}-07$ \\
\hline Species & $\mathrm{N}$ & $\mathrm{NH}$ & $\mathrm{NH} 2$ & NH3 & NNH \\
\hline Tomasz et al. & $7.46 \mathrm{E}-13$ & $8.24 \mathrm{E}-11$ & $1.46 \mathrm{E}-08$ & $3.89 \mathrm{E}-07$ & $2.97 \mathrm{E}-13$ \\
\hline Hamdi et al. & $2.79 \mathrm{E}-14$ & $1.20 \mathrm{E}-13$ & $4.31 \mathrm{E}-12$ & $8.20 \mathrm{E}-11$ & $1.49 \mathrm{E}-12$ \\
\hline Sepecies & NO & $\mathrm{NO} 2$ & $\mathrm{~N} 2 \mathrm{O}$ & HNO & $\mathrm{CN}$ \\
\hline Tomasz et al. & 1.42E-05 & $2.73 \mathrm{E}-05$ & $6.30 \mathrm{E}-06$ & 1.62E-09 & $5.62 \mathrm{E}-12$ \\
\hline Hamdi et al. & $1.29 \mathrm{E}-07$ & $4.98 \mathrm{E}-09$ & $6.26 \mathrm{E}-07$ & $6.60 \mathrm{E}-13$ & $1.63 \mathrm{E}-15$ \\
\hline Species & $\mathrm{HCN}$ & $\mathrm{H} 2 \mathrm{CN}$ & HCNN & $\mathrm{HCNO}$ & $\mathrm{HOCN}$ \\
\hline Tomasz et al. & $6.60 \mathrm{E}-07$ & $1.69 \mathrm{E}-15$ & $3.61 \mathrm{E}-19$ & $1.65 \mathrm{E}-05$ & 7.67E-07 \\
\hline Hamdi et al. & $1.54 \mathrm{E}-10$ & $1.14 \mathrm{E}-16$ & $4.75 \mathrm{E}-15$ & 7.77E-10 & $1.54 \mathrm{E}-10$ \\
\hline Species & $\mathrm{HNCO}$ & $\mathrm{NCO}$ & $\mathrm{N} 2$ & $\mathrm{AR}$ & $\mathrm{C} 3 \mathrm{H} 7$ \\
\hline Tomasz et al. & 1.09E-06 & 2.83E-09 & 7.37E-01 & $9.99 \mathrm{E}-05$ & $1.72 \mathrm{E}-29$ \\
\hline Hamdi et al. & $4.46 \mathrm{E}-10$ & 0.74288 & 0.74288 & $0.00 \mathrm{E}+00$ & $3.26 \mathrm{E}-28$ \\
\hline Species & C3H8 & $\mathrm{CH} 2 \mathrm{CHO}$ & $\mathrm{CH} 3 \mathrm{CHO}$ & & \\
\hline Tomasz et al. & 1.09E-29 & $5.96 \mathrm{E}-17$ & $1.26 \mathrm{E}-19$ & & \\
\hline Hamdi et al. & $1.07 \mathrm{E}-28$ & $4.09 \mathrm{E}-20$ & $4.09 \mathrm{E}-20$ & & \\
\hline
\end{tabular}

Discussion of the kinetics simulations: In this section, the kinetics simulation results are presented, focusing particularly on the influence of pressure $(\mathrm{P})$ and residence time $(\tau)$ on $\mathrm{NO}_{\mathrm{x}}$ and $\mathrm{CO}$ formations using the two detailed reaction kinetics mechanisms. The equivalence ratio $(\phi)$ has been kept at a constant value of $\phi=0.6$.

Influence of pressure: Figure 2 shows that the NO concentrations predicted by the Miller-bowman (M-B) mechanism feature no sensitivity to pressure, whereas with the GRI mechanism the predicted NO molar fractions decrease with increasing pressure and are much lower than the former ones.

The $\mathrm{NO}_{2}$ concentrations predicted by both mechanisms are strongly influenced by pressure and they both increase significantly with increasing pressure (Fig. 3).

The positive sensitivity of $\mathrm{N}_{2} \mathrm{O}$ to pressure is probably due to the increasing rate of the reaction:

$$
\mathrm{N}_{2}+\mathrm{O}+\mathrm{M} \rightarrow \mathrm{N}_{2} \mathrm{O}+\mathrm{M}
$$

with increasing pressure and the simultaneous decrease in the $\mathrm{N}_{2} \mathrm{O}$ consumption via the reaction:

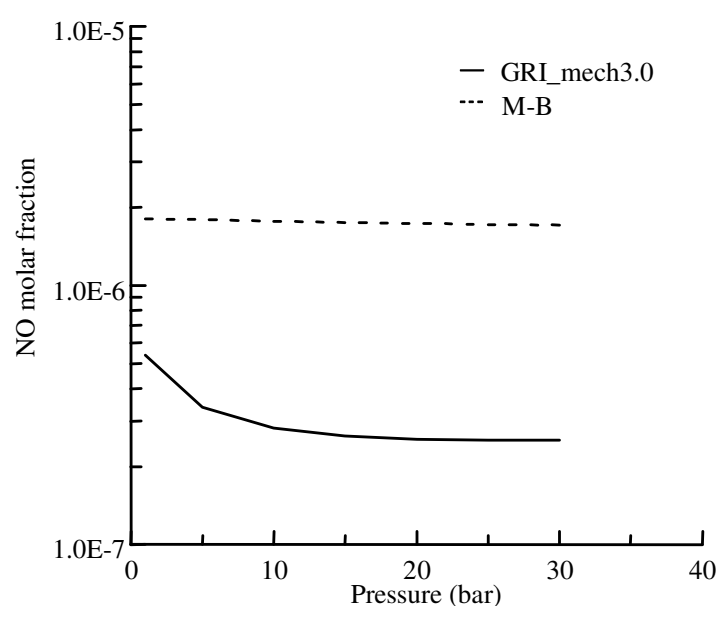

Fig. 2: Pressure effect on NO concentrations using the GRI and M-B mechanisms $\left(\mathrm{T}_{0}=1302.76 \mathrm{~K}\right.$; $\tau=10 \mathrm{~ms} ; \phi=0.6$ )

$\mathrm{N}_{2} \mathrm{O}+\mathrm{O} \rightarrow 2 \mathrm{NO}$

The former reaction rate increase due to the increase of $\mathrm{M}$ with increasing pressure and the later decreases with increasing pressure due to the strong 
Am. J. Environ. Sci., 4 (5): 535-543, 2008

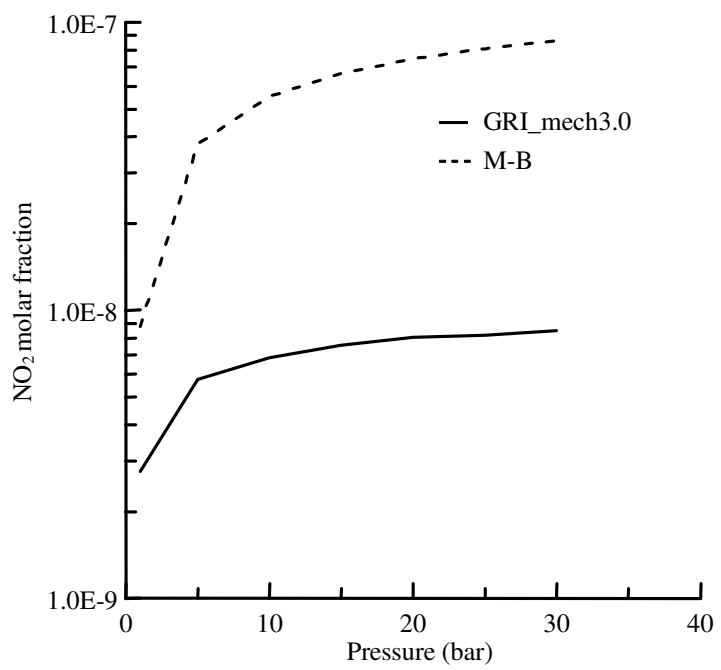

Fig. 3: Pressure effect on $\mathrm{NO}_{2}$ concentrations using the GRI and M-B mechanisms $\left(\mathrm{T}_{0}=1302.76 \mathrm{~K}\right.$; $\tau=10 \mathrm{~ms} ; \phi=0.6$ )

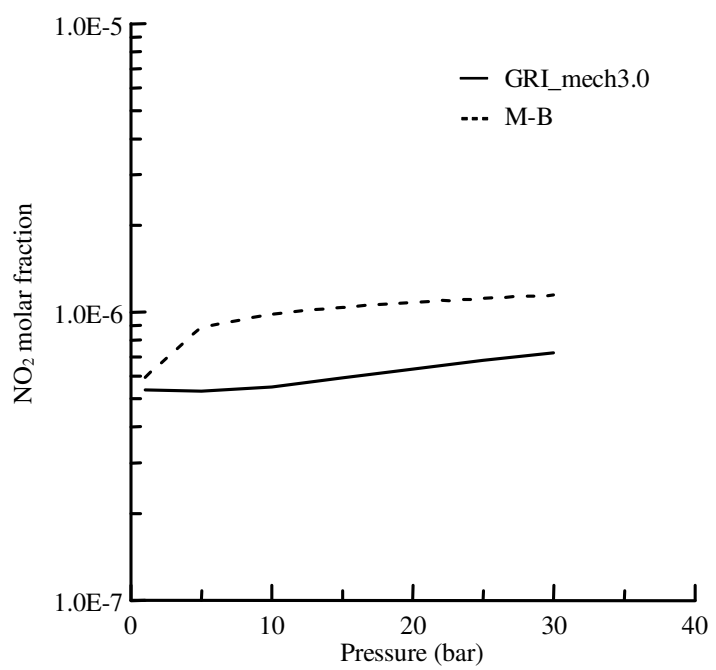

Fig. 4: Pressure effect on $\mathrm{N}_{2} \mathrm{O}$ concentrations using the GRI and M-B mechanisms $\left(\mathrm{T}_{0}=1302.76 \mathrm{~K}\right.$; $\tau=10 \mathrm{~ms} ; \phi=0.6$ )

negative sensitivity of the $\mathrm{O}$ radical concentration to pressure $^{[26]}$. It should also be noted that both Fig. 2 and 3 show that the M-B predictions are almost an order of magnitude higher than their GRI counter parts. This is very unusual knowing the kinetics details inherent in both mechanisms and it shows that proper mechanisms have to be used for different fuels and different operating conditions.

Figure 4 features the pressure effect on the $\mathrm{N}_{2} \mathrm{O}$ molar fractions. These also increase with pressure and

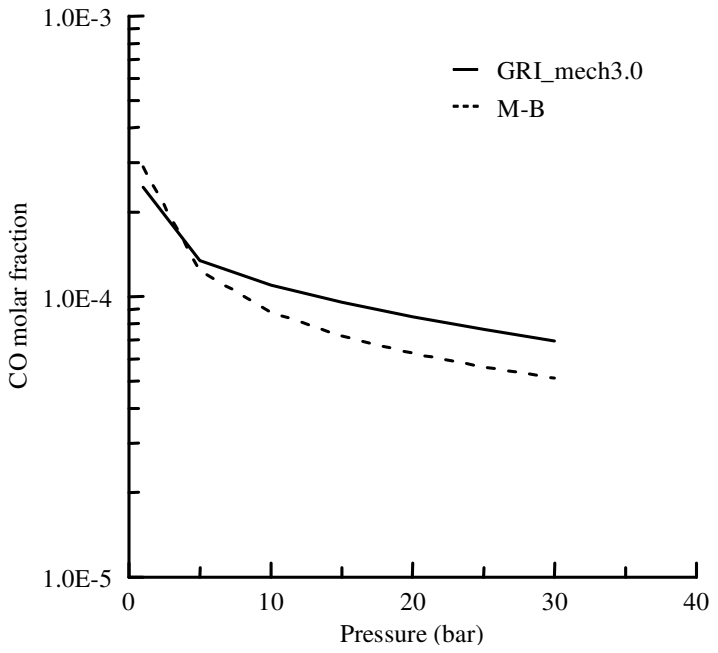

Fig. 5: Pressure effect on $\mathrm{CO}$ concentrations using the GRI and M-B mechanisms $\left(\mathrm{T}_{0}=1302.76 \mathrm{~K}\right.$; $\tau=10 \mathrm{~ms} ; \phi=0.6$ )

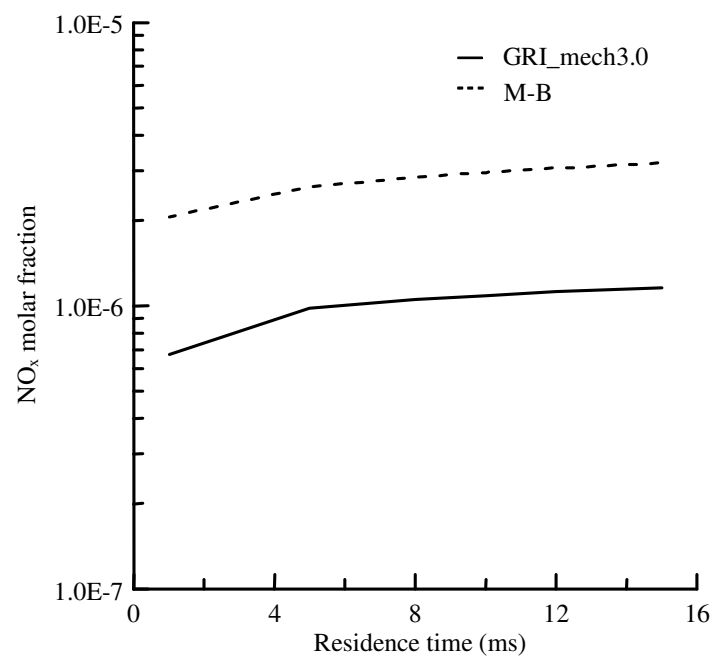

Fig. 6a: Influence of residence time on $\mathrm{NO}_{\mathrm{x}}\left(\mathrm{NO}+\mathrm{NO}_{2}\right)$ concentrations using the GRI and M-B mechanisms $\left(\mathrm{T}_{0}=1302.76 \mathrm{~K} ; \phi=0.6 ; \mathrm{P}=1\right.$ bar)

are different for the two mechanisms, but to a less extent than that for $\mathrm{NO}$ and $\mathrm{NO}_{2}$.

The predicted $\mathrm{CO}$ concentrations, using the both mechanisms decrease significantly with increasing pressure (Fig. 5); a pressure increase from 1-30 bares decreases the $\mathrm{CO}$ concentrations from $300-260 \mathrm{ppm}$ to 70-50 ppm (i.e. 75\%). The decrease in CO level is due to the increase in the overall combustion reaction rate with the increasing pressure $\left(\mathrm{p}^{\mathrm{m}-1} ; \mathrm{m}\right.$ : reaction order) enhancing the $\mathrm{CO}$ conversion to $\mathrm{CO}_{2}$. 
Am. J. Environ. Sci., 4 (5): 535-543, 2008

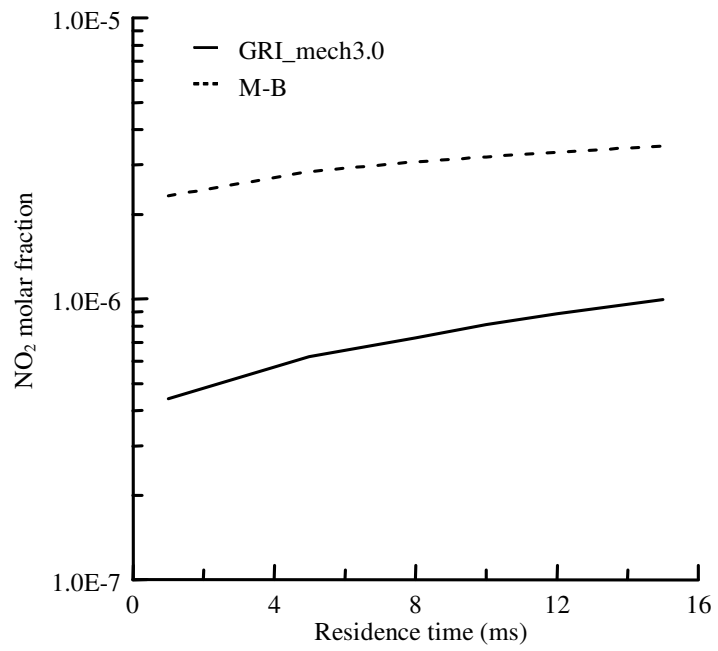

Fig. 6b: Influence of residence time on $\mathrm{NO}_{\mathrm{x}}\left(\mathrm{NO}+\mathrm{NO}_{2}\right)$ concentrations using the GRI and M-B mechanisms $\left(\mathrm{T}_{0}=1302.76 \mathrm{~K} ; \phi=0.6 ; \mathrm{P}=10\right)$

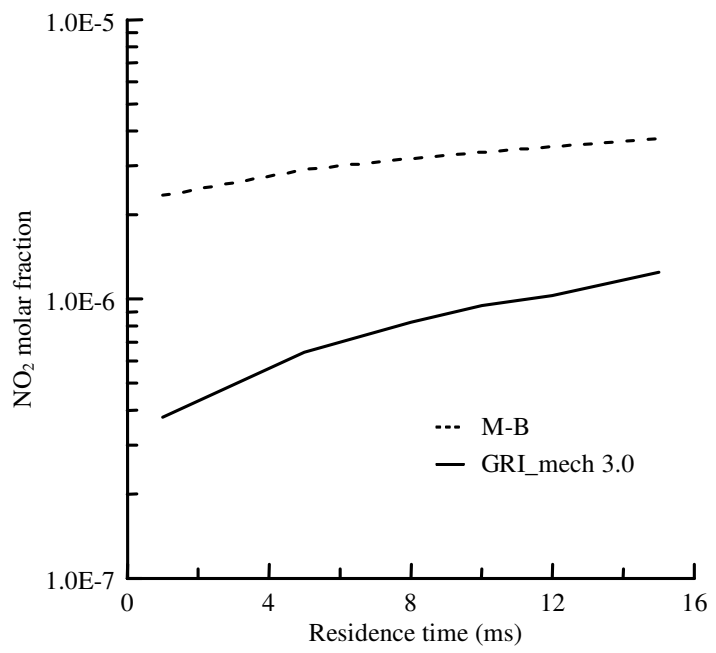

Fig. 6c: Influence of residence time on $\mathrm{NO}_{\mathrm{x}}\left(\mathrm{NO}+\mathrm{NO}_{2}\right)$ concentrations using the GRI and M-B mechanisms $\left(\mathrm{T}_{0}=1302.76 \mathrm{~K} ; \phi=0.6 ; \mathrm{P}=20\right.$ bar)

Influence of residence time: The influence of the residence time was studied in the second PSR in the range of $1-15 \mathrm{~ms}$ at pressure of 1,10 and 20 bars, equivalence ratio of 0.6 and temperature of $1302.76 \mathrm{~K}$ and with higher recirculation rate. The predicted trends of $\mathrm{NO}_{\mathrm{x}}\left(\mathrm{NO}+\mathrm{NO}_{2}\right), \quad \mathrm{N}_{2} \mathrm{O}$ and $\mathrm{CO}$ using both mechanisms are shown in Fig. 6-8.

The $\mathrm{NO}_{\mathrm{x}}$ concentrations predicted by both mechanisms increase with increasing residence time at

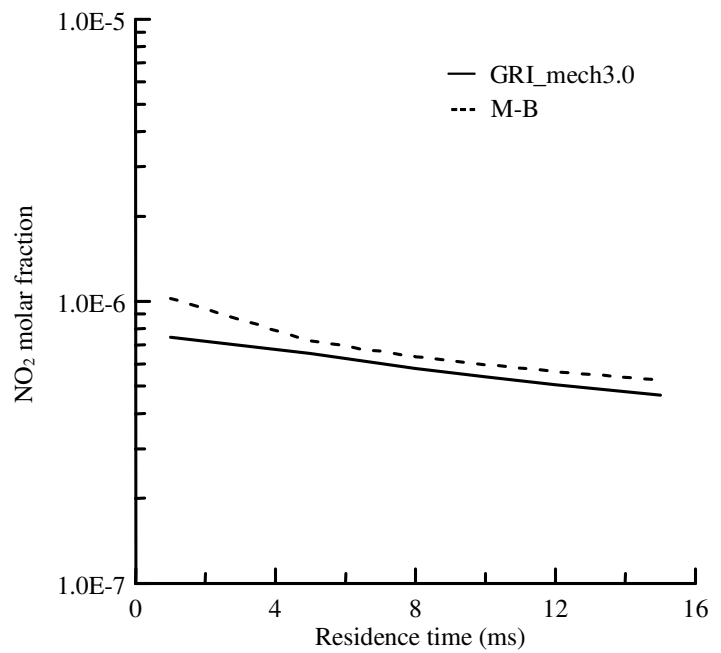

Fig. 7a: Influence of residence time on $\mathrm{N}_{2} \mathrm{O}$ concentration using the GRI and M-B mechanisms $\left(\mathrm{T}_{0}=1302.76 \mathrm{~K} ; \phi=0.6 ; \mathrm{P}=1\right.$ bar)

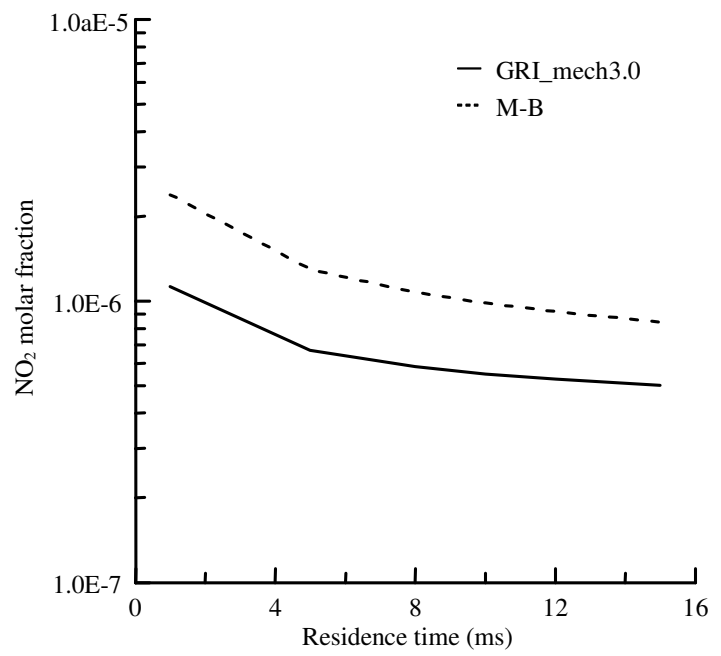

Fig. 7b: Influence of residence time on $\mathrm{N}_{2} \mathrm{O}$ concentration using the GRI and M-B mechanisms $\left(\mathrm{T}_{0}=1302.76 \mathrm{~K} ; \phi=0.6 ; \mathrm{P}=10\right.$ bar)

all pressures, the increase being slightly weaker at higher pressure (Fig. 6a-c). The diminishing influence of residence time with increasing pressure is due to the fact that $\mathrm{NO}_{\mathrm{x}}$ formation reactions reach equilibrium faster at higher pressures. However the discrepancy between the predictions of the two mechanisms is still very obvious. 
Am. J. Environ. Sci., 4 (5): 535-543, 2008

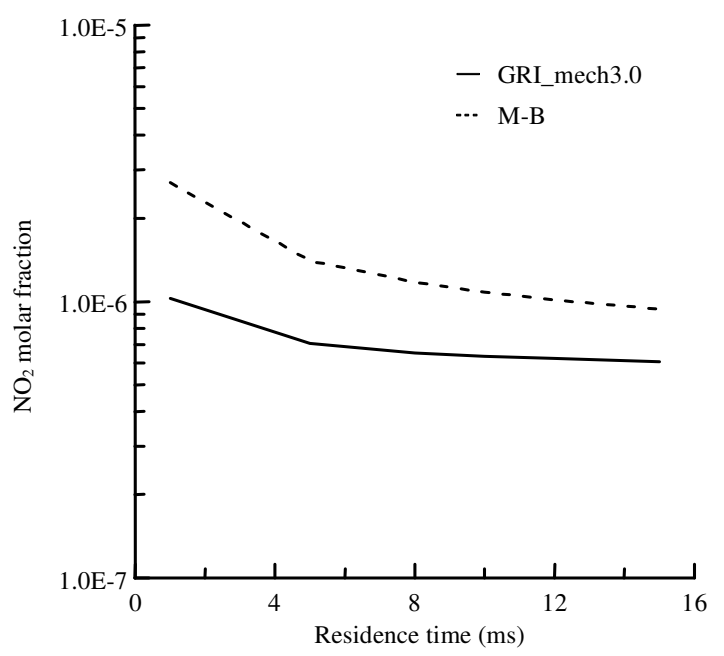

Fig. 7c: Influence of residence time on $\mathrm{N}_{2} \mathrm{O}$ concentration using the GRI and M-B mechanisms $\left(\mathrm{T}_{0}=1302.76 \mathrm{~K} ; \phi=0.6 ; \mathrm{P}=20\right.$ bar)

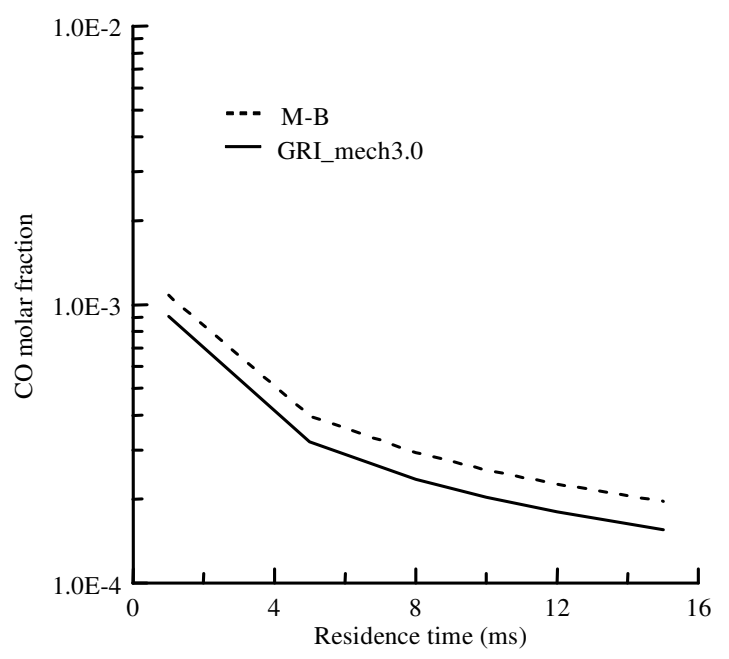

Fig. 8a: Influence of residence time on $\mathrm{CO}$ concentration using the GRI and M-B mechanisms $\left(\mathrm{T}_{0}=1302.76 \mathrm{~K} ; \phi=0.6 ; \mathrm{P}=1\right.$ bar)

$\mathrm{N}_{2} \mathrm{O}$ concentrations decrease with increasing residence time at all pressures and for both reaction mechanisms (Fig. 7a-c). Increasing residence time promotes the conversion of $\mathrm{N}_{2} \mathrm{O}$ to $\mathrm{NO}$, which explains the negative sensitivity of $\mathrm{N}_{2} \mathrm{O}$ to residence time.

The $\mathrm{CO}$ concentrations decrease very fast with increasing residence time at 1,10 and 20 bars (Fig. 8ac). $\mathrm{CO}$ reacts to $\mathrm{CO}_{2}$ almost exclusively through the reaction:

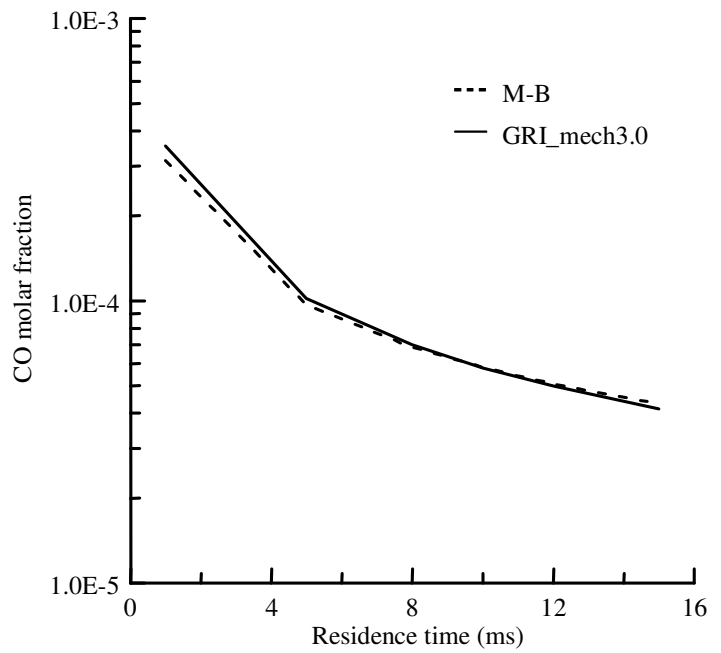

Fig. 8b: Influence of residence time on $\mathrm{CO}$ concentration using the GRI and M-B mechanisms $\left(\mathrm{T}_{0}=1302.76 \mathrm{~K} ; \phi=0.6 ; \mathrm{P}=10\right.$ bar)

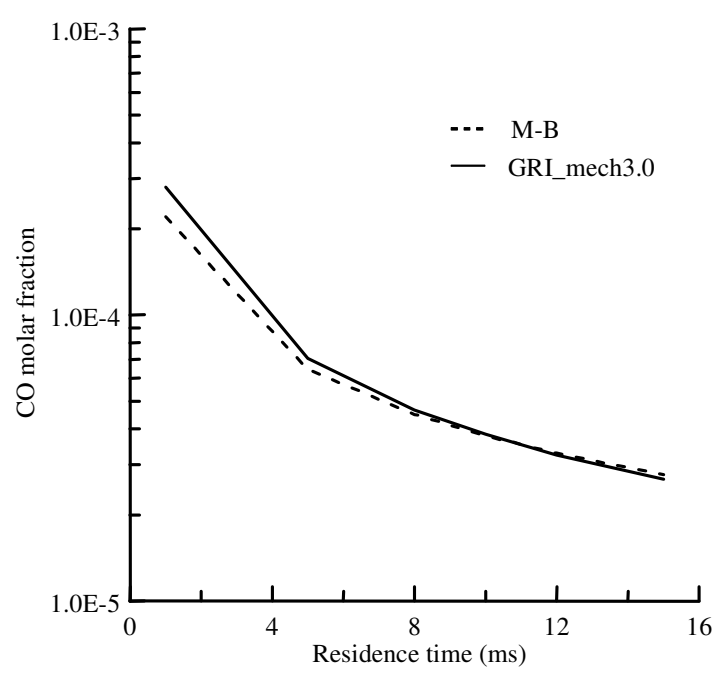

Fig. 8c: Influence of residence time on $\mathrm{CO}$ concentration using the GRI and M-B mechanisms $\left(\mathrm{T}_{0}=1302.76 \mathrm{~K} ; \phi=0.6 ; \mathrm{P}=20\right.$ bar)

$\mathrm{CO}+\mathrm{OH} \rightarrow \mathrm{CO}_{2}+\mathrm{H}$

which competes with the reaction:

$$
\mathrm{CH}_{4}+\mathrm{OH} \rightarrow \mathrm{CH}_{3}+\mathrm{H}_{2} \mathrm{O}
$$

for the $\mathrm{OH}$ radical. At the beginning of the reaction scheme the fuel concentration is high and the reaction 
rate of $\left(R_{4}\right)$ is much higher than that of reaction $\left(R_{3}\right)$. Therefore $\mathrm{CO}_{2}$ is not extensively formed until a large part of the fuel has been oxidized and the CO level has increased. By increasing the residence time the available time for the complete $\mathrm{CH}_{4}$ conversion to $\mathrm{CO}_{2}$ increase, thereby the $\mathrm{CO}$ level is decreased. It should be noted here that unlike the NOx predictions, the discrepancy between the two mechanisms is very slight for $\mathrm{CO}$ level predictions.

\section{CONCLUSION}

Numerical modeling of the flameless oxidation for a gas turbine combustor have been carried out using a numerical investigation of the combustion and pollutant formation in a series of two ideal perfectly stirred reactor model and the detailed chemistry approach. The numerical investigation showed that the predictions using the Miller-bowman mechanism deviate from the predictions of the GRI3.0 mechanisms in many aspects. The $\mathrm{NO}_{\mathrm{x}}$ pressure dependence deviate the most; where the $\mathrm{NO}_{\mathrm{x}}$ concentrations of the Miller-bowman mechanism stay almost unchanged with increasing pressure, the GRI mechanism ones feature a decreasing trend especially up to 10 bars. Globally it is shown that the details embedded in these complex reaction kinetics mechanisms are probably good for flame structure and other combustion studies but still need improvement and selectivity toward pollutant formation and especially under different operating conditions.

\section{REFERENCES}

1. Wünning, J.A. and J.G. Wünning, 1997. Flameless oxidation to reduce thermal NO formation. Prog. Energy Combust. Sci., 23: 81-94.

2. Katski, M. and T. Hasegawa, 1998. The science and technology of combustion in highly preheated air. The 27th Symposium (International) on Combustion, pp: 3135-3146.

3. Tanaka, R. and T. Hasegawa, 1997. Innovative technology to change flame characteristics with highly preheated air combustion. In: Proceeding of Japanese Flame Days 1997, Osaka, Japan, pp: $129-150$.

4. Gupta, A.K. and Z. Li, 1997. Effect of fuel property on the structure of highly preheated air flames. ASME International Joint Power Generation Conference, Denver CO, ASME EC, vol. 5, pp: 247-257.

5. Gupta, A.K., S. Bolz and T. Hasegawa, 1999. Effect of air preheat temperature and oxygen concentration on flame structure and emissions. ASME J. Energy Resour. Technol., 121: 20-216.
6. Mochida, S. and T. Hasegawa, 2000. Development of a combustion diagnostics method on advanced industrial furnaces utilizing high temperature air combustion. In: Proceedings of the 2nd International Seminar on High Temperature Combustion in Industrial Furnaces, JernkonotoretKTH, Stockholm, Seweden.

7. Balsiak, W. and B. Lindblad, 2000. Highly preheated air combustion research in Sweden. In: Proceeding of the 2nd International Seminar on High Temperature Combustion in Industrial Furnaces, Jernkonotoret-KTH, Stockholm, Seweden.

8. Verlaan, A.L., S. Orsino, N. Lallemant and R. Weber, 1998. Fluid flow and mixing in a furnace equipped with the low- $\mathrm{NO}_{\mathrm{x}}$ regenerative burner of Nippon Furnace Kogyo. The results of the HTAC97 trials, IFRF Doc. $\mathrm{N}^{\circ}$ F46/y/1.

9. Weber, R., A.L. Verlaan, S. Orsino and N. Lallemant, 1999. On emerging furnace design methodology that provides substantial energy savings and drastic reduction in $\mathrm{CO}_{2}, \mathrm{CO}$ and $\mathrm{NO}_{\mathrm{x}}$ emissions. J. Inst. Energy, 72: 77-83.

10. Ishiguro, T., S. Tsuge, T. Furuhata, K. Kitigawa, N. Aral, T. Hasegawa, R. Tanaka and A.K. Gupta, 1998. Homogenization and stabilization during combustion of hydrocarbons with preheated air. Proc. Combust. Inst., 27: 3205-3213.

11. Plessing, T., N. Peters and J.G. Wünning, 1998. Laser optical investigation of highly preheated combustion with exhaust gas recirculation. Proc. Combust. Inst., 27: 3197-3204.

12. De Joannon, M., A. Saponaro and A. Cavaliere, 2000. Zero-dimensional analysis of methane diluted oxidation in rich conditions. Proc. Combust. Inst., 28: 1639-1646.

13. Cavaliere, A. and M. de Joannon, 2004. Mild combustion. Prog. Energy Combust. Sci., 30: 329366.

14. Levy, Y., V. Sherbaum and P. Arfi, 2004. Basic thermodynamics of FLOXCOM, the low- $\mathrm{NO}_{x}$ gas turbines adiabatic combustor. Applied Therm. Eng., 24: 1593-1605.

15. Hamdi, M., H. Benticha and M. Sassi, 2006. Detailed chemical modeling of flameless combustion turbine for pollution prevention. Int. J. Environ. Pollut. (In Press).

16. Miller, J.A. and C.T. Bowman, 1989. Mechanism and modeling of nitrogen chemistry in combustion. Prog. Energy Combust. Sci., 15: 287-338.

17. Smith, G.P., D.M. Golden, M. Frenklach, N.W. Moriarty, B. Eiteneer, M. Goldenberg, C.T. Bowman, R. Hanson, S. Song, W.C. Gardiner Jr, V. Lissianski and Z. Qin. From: http://www.me.berkely.edu/gri-mech/. 
18. Miller, J.A., R.J. Kee, F.M. Rupley and E. Meeks, 1996. CHEMKIN III: A Fortran chemical kinetics package for the analysis of gas-phase chemical and plasma kinetics. Sandia Report SAND 96-2816, Sandia National Laboratories, Livermore, USA.

19. Tomasz O. and B. Janusz, 2001. Flameless oxidation at the GT26 gas turbine: Numerical study via full chemistry. Task Quarterly $5 \mathrm{~N}^{\circ} 2,2001$, pp: 239-246.

20. Bruno, C. and L. Vallini, 1999. Flameless combustion and its application to aeroengines. In: 14th International Symposium on Air Breathing Engines, September 5-10, Florence, Italy.

21. Coelho P.J. and N. Peters, 2001. Numerical simulation of a mild combustion Burner. Combust. Flame, 124: 503-518.

22. Ishii, T., C. Zhang and S. Sugiyama, 1998. Numerical simulation of highly preheated air combustion in an industrial furnace. ASME J. Energy Resour. Technol., 120: 276-284.
23. Quinqueneau, A., P.F. Miquel, L.M. Dearden, G.T. Spence, A. Williams and B.J. Wills, 1998. Experimental and theoretical investigation of low$\mathrm{NO}_{\mathrm{x}}$ high temperature industrial burner. In: International Gas Research Conference, pp: 225-236.

24. Quinqueneau, A., A. Touzet and M. Oger, 2001. Experimental studies on regenerative industrial burners operating in the flameless oxidation mode. In: 13th IFRF Member's Conference, May 16-18, 2001.

25. Pesenti, B., P. Evrard and P. Lybaert, 2001. $\mathrm{NO}_{\mathrm{x}}$ production and radiative heat transfer from an autoregenerative flameless oxidation burner. In: 4th Symposium on High Temperature Air Combustion and Gasification, Rome 2001.

26. Steele, R.C., P.C. Malte, D.G. Nicol and J.C. Kramlich, 1995. $\mathrm{NO}_{\mathrm{x}}$ and $\mathrm{N}_{2} \mathrm{O}$ in lean premixed jet-stirred flames. Combust. Flame, 100: 440-449. 